\title{
STUDIES ON SOIL ALGAL FLORA IN KAFR EL- SHEIKH GOVERNORATE, EGYPT
}

\author{
Ahmed D. El-Gamal", Nady A. E. Ghanem ${ }^{*}$, Eisha Y. El-Ayouty ${ }^{* *}$ and \\ Ehab F. Shehata" \\ *Fac. Sci., Bot. Dept .Al-Azhar Univ. Cairo-Egypt. \\ **Fac. Sci., Bot. Dep. Cairo Univ. Giza, Egypt. \\ e-mail:ahmed46da@yahoo.com
}

\begin{abstract}
In this study, soil samples were collected from ten different regions comprising the main ten cities of Kafr El-Sheikh Governorate during 2002. The Physico-chemical characteristics of the soil were investigated. The results showed remarkable differences among various sites. Twenty six genera including 40 species of algae were isolated and identified from the soil samples. They were 11 genera including 25 species of cyanobacteria and 15 genera including 15 species of green algae. The physico-chemical characteristics of soils in relation to algal distribution have also been considered.
\end{abstract}

Key words: Cyanobacteria- Green algal flora- Physical and chemical characteristics of Kafr El-Sheikh soil.

\section{Introduction}

The study of Egyptian algal flora is still a non-depletion source, although numerous studies were carried out (Fremy and Nasr, 1938; El-Ayouty and Ayyad, 1972; Kobbia and Shabana, 1988; Ahmed 1994; Mahmoud et al., 2000; Fathi and Zaki, 2003; Shanab, 2006). In Egypt, more intensive studies needed to be done dealing with different algal aspects that may help to understand the prominent role played by algae in stabilization of the ecosystems. In this respect, Shields and Durrell (1964) concluded that the species composition of soil algal populations is less affected by the chemical nature of the substrate than by certain physical properties which influence soil moisture levels.

Little studies were done on the effect of soil texture on the algal distribution (Metting, 1981). However, soil texture strongly affects the presence of diatoms (Lund, 1945) and blue-green algae species (Shields and Drouet, 1962). In similar studies, Salama et al. (1973) concluded that soil texture interferes in the selection and distribution of soil microorganisms. The presence of fine particles in one soil type increased the availability to retain more moisture and more inorganic nutrients needed by algal growth (Osman et al., 2003). Handley and Michelle (2003) stated that the increase of $\mathrm{pH}$ and salinity was negatively correlated with species richness. Ibraheem (2003) also outlined that the increase or decrease in species number went parallel to $\mathrm{pH}$ and organic carbon. 
Soil algae help in aggregation of soil particles and sand grains to form microbial crusts (Hu et al., 2003) as a result of that, they stabilize the soil surface of bare eroded soils against further erosion and soil removal by wind, improve infiltration of water into the soil, reduce water loss, improve soil texture by aggregating soil particles, add organic matter to the soil, help to solubilize certain minerals, provide a favorable habitat for seed germination and have been suggested as biofertilizers as well (Gray and Williams, 1971; Bailey et al., 1973; Round, 1981; Darley, 1982 and Painter, 1993). Therefore, the present study has been undertaken to study the soil algal flora in Kafr El-Sheikh Governorate, Egypt. Moreover, the distribution and abundance of soil algae was discussed in the light of physicochemical characteristics as well as the edaphic factors of soil.

\section{Materials and Methods}

Soil samples: Five randomly-selected soil samples were collected from 10 different sites during 2002 in Kafr El-Sheikh Governorate, Egypt (Fig.1). About $10 \mathrm{~cm}$ diameter soil cores reaching $4-5 \mathrm{~cm}$ below the surface of the soil gathered and placed in sterile plastic bags. Samples were transported to the laboratory within 24 hours of collection. Table 1 describes the nature of each soil as well as its cultivation status.

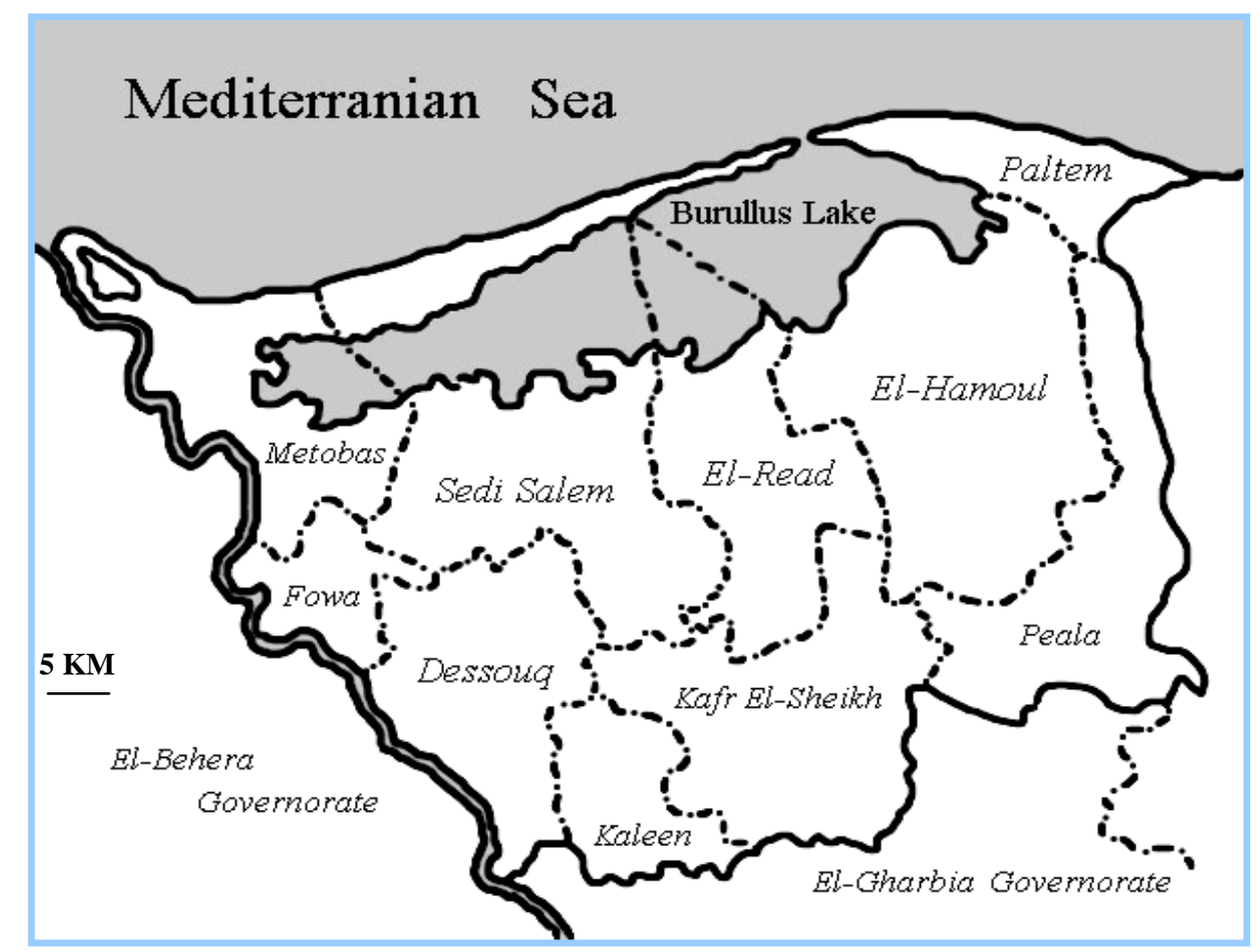

Figure 1: Map showing Kafr El-Sheikh Governorate. 
Table 1: Description of sampling locations in this study.

\begin{tabular}{|c|c|c|c|}
\hline $\begin{array}{c}\text { Soil } \\
\text { sample }\end{array}$ & $\begin{array}{c}\text { Location of } \\
\text { sampling }\end{array}$ & $\begin{array}{c}\text { Nature } \\
\text { of soil }\end{array}$ & $\begin{array}{c}\text { Cultivation status } \\
\text { (at the time of sampling) }\end{array}$ \\
\hline 1 & Baltem & Saline-sodic & Non-cultivated (non cultivated soil) \\
\hline 2 & Sedi-Salem & Saline-sodic & Non-cultivated ( non cultivated soil) \\
\hline 3 & Metobas & Normal & Cultivated with Bean (Vicia faba). \\
\hline 4 & El-Hamoul & Normal & Cultivated with Wheat (Triticum vulgare). \\
\hline 5 & El-Read & Saline & Non-cultivated ( non cultivated soil) \\
\hline 6 & Fowa & Normal & Cultivated with Bean (Vicia faba). \\
\hline 7 & Dessouq & Normal & Cultivated with Clover (Trifolium alexandrium). \\
\hline 8 & Kaleen & Normal & Cultivated with Wheat (Triticum vulgare). \\
\hline 9 & Kafr El-Sheikh & Normal & Cultivated with Clover (Trifolium alexandrium). \\
\hline 10 & Beala & Normal & Cultivated with Wheat (Triticum vulgare). \\
\hline
\end{tabular}

\section{Physical and chemical analysis of soil:}

Particles size analysis of the different air dried soil samples was determined according to Shubert and Starks (1980). The determinations of maximum water holding capacity (M.W.H.C.), gravitational, hygroscopic and capillary water of soil were also determined as described by El-Gamal (1995).

pH value was measured by HANNA HI $9318 \mathrm{pH}$ meter. Total watersoluble salts (T.W.S.S.) carbonates; bicarbonates and chlorides were determined according to Jackson (1977). Electrical conductivity of soil extract $\left(\mathrm{EC}_{\mathrm{e}}\right)$ was determined using digital electric conductivity meter (WTW, D-82362 EC). Organic carbon was determined by Walkely and Black (1934) method and modified by Piper (1950). Complex titration method (Page et al., 1982) was used in determination of $\mathrm{Ca}$ and $\mathrm{Ca}+\mathrm{Mg}$. Flame photometric technique was used for $\mathrm{Na}$ and $\mathrm{K}$ determination in the investigated soil samples using $\mathrm{Na}$ and $\mathrm{K}$ standard solution.

\section{Culturing and isolation of algae:}

The following methods were applied on air-dried soil samples, using Zmedium (Staub, 1961) and modified Watanabe medium (El-Nawawy et al.,1958) for isolation and culturing of algae: 
Semi-solid medium as described by El-Ayouty and Ayyad, (1972) and filter paper method as recommended by Esmarch (1914) were applied. About $10 \mathrm{~g}$ of the soil sample were placed also in flasks containing $100 \mathrm{ml}$ of the sterilized liquid medium. The Petri-dishes as well as flasks were incubated at $30^{\circ} \mathrm{C}$ under continuous light (2500 lux).

The identification of algae was carried out using the following criteria: Thallus color, thallus morphology, and dimension and size of heterocysts, vegetative and reproductive cells were put into consideration. Heterocyst-forming blue-green algae were also cultured in nitrogen-free Z-medium.( El-Gamal, 1995)The description of isolated algae was supported by colored photographs.

Statistical analysis: The data were statistically analyzed using Pearson correlation coefficient (r) at $\mathrm{P}<0.05$ and $\mathrm{P}<0.01$. All data were performed by SPSS statistical PC program (1997).

\section{Results}

The results of the mechanical analysis of the soil samples showed that some soil samples, to some extent, are similar in the nature of soil texture, while the others are different. From Table 2, the soils samples 1, 2, 3, 5, 6, 9 and 10 had the highest fraction of very fine sand $(42.7,40.5,33.96,31.98,34.57,31.68$ and $31.84 \%$, respectively), where as the soils $2,3,5$ and 6 , had the lowest fractions of stones among the samples $(4.3,4.34,4.88$ and $5.66 \%$, respectively). It was found that the soil 1 has no stones fraction and fine gravels are represented by the lowest fraction $(0.66 \%)$. The highest percentages of fine sand were represented in soil 1, 4, 7, 8 and 10 (38.07, 32.16, 40.16, 37.46, and $37.21 \%$, respectively). Soils samples 1 and 10 represented the lowest fractions of silt and clay (2.040 and $2.710 \%$, respectively). Also, Table 2 summarizes the results of maximum water holding capacities of the investigated soils. The data revealed that soils 1 and 10 have the lowest levels of water holding capacity (45.09 and 55.05\%, respectively). On the contrary, soil samples 5 and 6 had the highest levels of maximum water holding capacity (94.32 and $91.27 \%$, respectively). Soils 5 and 6 had the lowest values of gravitational water ( 80.34 and $81 \%$, respectively) (Table 2 ). The highest values of the gravitational water were recorded in soil samples 1 and 10 (90.67 and $87.67 \%$, respectively). The results revealed that soil 3 shows the highest percentage of hygroscopic water $(10.14 \%)$, while the lowest percentage was observed in soil $1(2.42 \%)$. On the other hand, soils 5 and 6 seemed to be the highest in percentages of capillary water (12.34 and $10.68 \%$, respectively), followed by soil $2(10.05 \%)$. While soils 1 and 10 had the lowest percentages (6.89 and $5.54 \%$, respectively) (Table 2). 
Studies on soil algal flora in Kafr El-Sheikh Governorate, Egypt

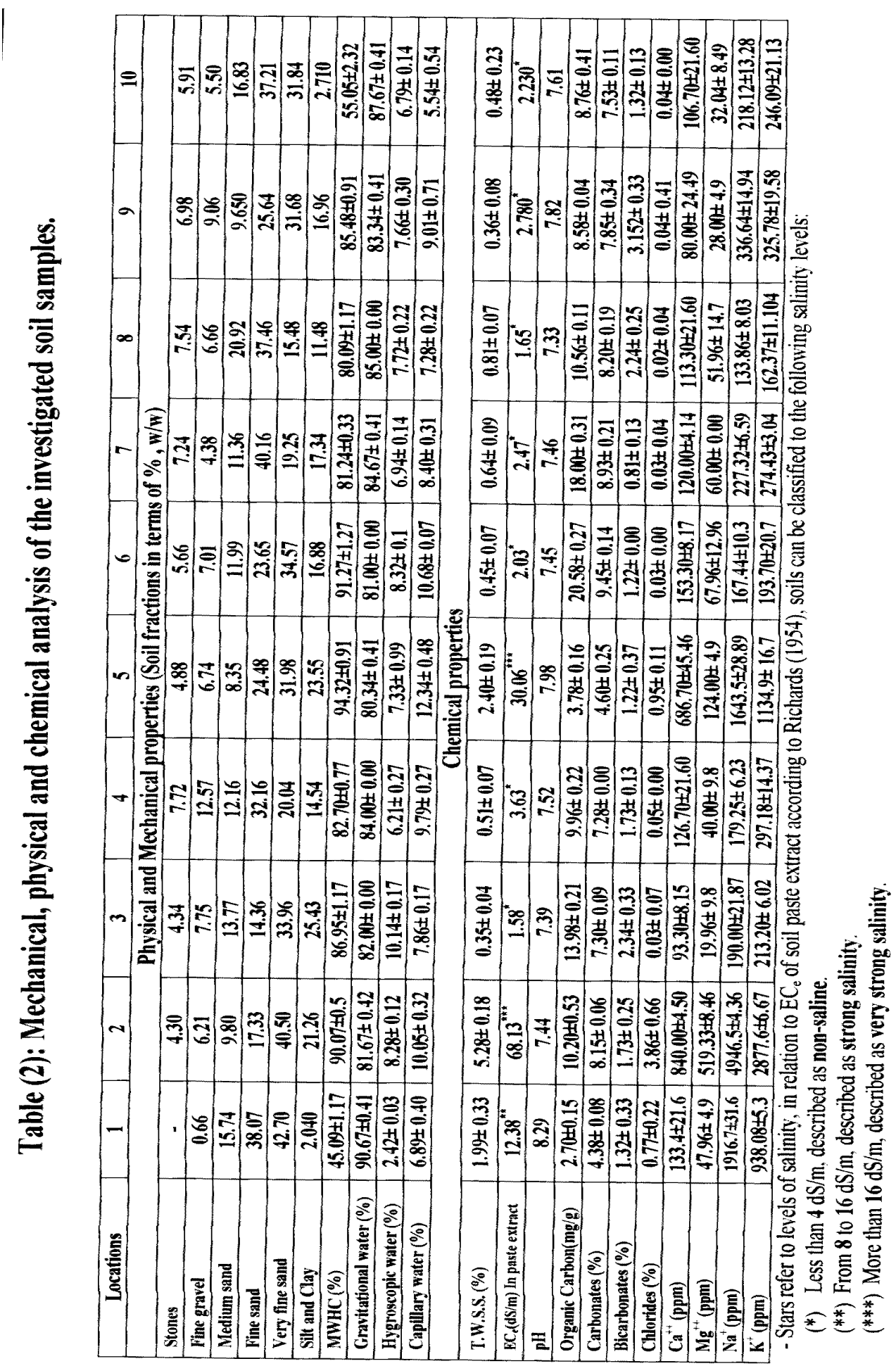


It was noticed that, soil 2 had the highest values of both total water soluble salts and electrical conductivity $(5.28 \%$ and $68.13 \mathrm{dS} / \mathrm{m}$ in soil extract, respectively). On the contrary, soil 3 showed the lowest values of both total water soluble salts and electrical conductivity $(0.35 \%$ and $1.58 \mathrm{dS} / \mathrm{m}$ in soil extract, respectively). However, soil samples 1 and 5 also demonstrated relative high values of total water soluble salts and electrical conductivity (1.99 and $2.40 \%$ and 12.38 and $30.06 \mathrm{dS} / \mathrm{m}$ in soil extract, respectively).

The results in Table 2 showed that $\mathrm{pH}$ values in soil extract were almost alkaline in all soil samples. For organic carbon content, the maximum value was recorded in the soil $6(20.58 \mathrm{mg} / \mathrm{g})$, simultaneously, this soil had the highest percentage of carbonates $(9.45 \%)$, while the lowest content of the organic carbon and carbonate percentage were found in soil $1(2.7 \mathrm{mg} / \mathrm{g}$ and $4.38 \%$, respectively). It was also found that the highest percentage of bicarbonate was recorded in soil $9(3.152 \%)$, while the lowest percentage was found in soil 7 $(0.81 \%)$ (Table 2$)$.

The percentage of chlorides in soil samples showed that soil sample 2 recorded the highest percentage of chlorides (3.86\%). However, soil 8 had the lowest percentage $(0.02 \%)$. Meanwhile, soil samples 1 and 5 also exhibited relative high values of chlorides ( 0.77 and $0.95 \%$, respectively). The analysis of metal ions indicated that soil 2 contains the highest values of $\mathrm{Ca}^{++}, \mathrm{Mg}^{++}, \mathrm{Na}^{+}$and $\mathrm{K}^{+}(840,519.3,4946.5$ and $2877.6 \mathrm{ppm}$, respectively) (Table 2). The lowest values were differed among soils, i.e. the lowest value of $\mathrm{Ca}^{++}(80 \mathrm{ppm})$ was recorded in soil 9, and the lowest value of $\mathrm{Mg}^{+2}$ (19.96 ppm) was recorded in soil 3 . While, the lowest values of $\mathrm{Na}^{+}$and $\mathrm{K}^{+}$(133.86 and $162.37 \mathrm{ppm}$, respectively) was recorded in soil 8 (Table 2).

Twenty six genera including 40 species were isolated from the soils. Eleven genera including 25 species of cyanobacteria and 15 genera including 15 species of green algae were identified (Table 3). Illustrations of the identified taxa are given in Plates 1-11.

Table (4) showed the correlation coefficient between soil characters and the number of algal species in investigated soil samples. The present results revealed that a significant positive correlation between cyanobacteria species and very fine sand, O.C., carbonates, $\mathrm{Mg}^{+2}, \mathrm{Na}^{+}$and $\mathrm{K}^{+}$ions in all investigated locations. Also, silt and clay, MWHC, capillary water, bicarbonates exhibited a significant positive correlation with green algal species. On the other hand, a significant negative correlation was recorded between chlorophyta species and chlorides, $\mathrm{Ca}^{+2}, \mathrm{Mg}^{+2}, \mathrm{Na}^{+}$and $\mathrm{K}^{+}$ions. 
Table (3): A lists of the isolated algae from soil samples and their occurrence in different sites at Kafr El-Sheikh during 2002.

\begin{tabular}{|c|c|c|c|c|c|c|c|c|c|c|}
\hline \multirow{2}{*}{ Isolated algae* } & \multicolumn{10}{|c|}{ Sites } \\
\hline & 1 & 2 & 3 & 4 & 5 & 6 & 7 & 8 & 9 & 10 \\
\hline Chroococcus minor & & & $\checkmark$ & & & $\checkmark$ & & & & \\
\hline Chroococcus turgidus & & & $\checkmark$ & & & & & & & \\
\hline Aphanothece castagenei & & & $\checkmark$ & & & & & & & \\
\hline Aphanothece stagnina & & $\checkmark$ & & & & & & & & $\checkmark$ \\
\hline Spirulina subsalsa & & $\checkmark$ & & & & & & & & \\
\hline Arthrospira gomontiana var. crassa & & & & $\checkmark$ & & & & & & $\checkmark$ \\
\hline Oscillatoria amoena & & & & & & & $\checkmark$ & & & \\
\hline Oscillatoria anguina & & & & $\checkmark$ & & & & & & \\
\hline Oscillatoria nigra & & & & & & $\checkmark$ & & & & \\
\hline Oscillatoria sancta & & & & & & $\checkmark$ & & & $\checkmark$ & \\
\hline Oscillatoria subbrevis & & & & $\checkmark$ & & & & & & \\
\hline Oscillatoria sp. (1) & $\checkmark$ & & & & & & & & & \\
\hline Oscillatoria sp. (2) & $\checkmark$ & & & & & $\checkmark$ & $\checkmark$ & & & \\
\hline Phormidium ambiguum & & & & & & $\checkmark$ & & & & \\
\hline Lyngbya birgei & & & & & & & & $\checkmark$ & & \\
\hline Lyngbya hieronymusli & & $\checkmark$ & & & $\checkmark$ & & & & & \\
\hline Lyngbya martensiana & & & & & & $\checkmark$ & & & & \\
\hline Anabaena torulosa & & $\checkmark$ & & $\bar{\checkmark}$ & & & & & & \\
\hline Anabaena wisconsinense & & & & & & $\checkmark$ & & & & \\
\hline Anabaena variabilis & $\checkmark$ & & & & & & & & & \\
\hline Nostoc linckia & & $\checkmark$ & & & & & & & & \\
\hline Nostoc paludosum & $\checkmark$ & & & & & & & & & \\
\hline Nostoc sp. & & & $\checkmark$ & & & & & & & \\
\hline Cylindrospermum majus & & $\checkmark$ & & & & $\checkmark$ & & & & \\
\hline Tolypothrix tenuis & & & & & & & & & & $\checkmark$ \\
\hline Chlamydomonas globosa & & & $\checkmark$ & & & & & $\checkmark$ & & \\
\hline Pandorina sp. & & & & & & & & & $\checkmark$ & \\
\hline Eudorina sp. & & & & & & $\checkmark$ & & & $\checkmark$ & \\
\hline Gloeocystis major & $\checkmark$ & & & & $\checkmark$ & & & & & \\
\hline Chlorococcum humicola & $\checkmark$ & & & & & & $\checkmark$ & & & \\
\hline Characium acuminatum & & & & & $\checkmark$ & & & & & \\
\hline Chlorella vulgaris & & & & & & $\checkmark$ & & & $\checkmark$ & \\
\hline Ankistrodesmus braunii & & & & & & $\checkmark$ & & & $\checkmark$ & \\
\hline Scenedesmus dimorphus & & & & & & $\checkmark$ & $\checkmark$ & & & \\
\hline Protococcus viridis & & & & & $\checkmark$ & & & & & \\
\hline Ulothrix cylindricum & & & $\checkmark$ & & & & & $\checkmark$ & $\checkmark$ & \\
\hline Oedogonium lautumniarum & & & $\bar{\checkmark}$ & & & $\checkmark$ & & & $\checkmark$ & \\
\hline Spirogyra sp. & & & $\checkmark$ & & & & & & & \\
\hline Closterium parvulum & & & $\checkmark$ & & $\checkmark$ & & & & $\checkmark$ & \\
\hline Cosmarium melanosporum & & & & & & & & $\bar{\checkmark}$ & $\checkmark$ & \\
\hline Total number of isolates & 6 & 6 & 9 & 4 & 5 & 13 & 4 & 4 & 9 & 3 \\
\hline
\end{tabular}

* The algal genera are arranged within the Prescott's arrangement mentioned in his key (1973). 


\section{Plate 1}

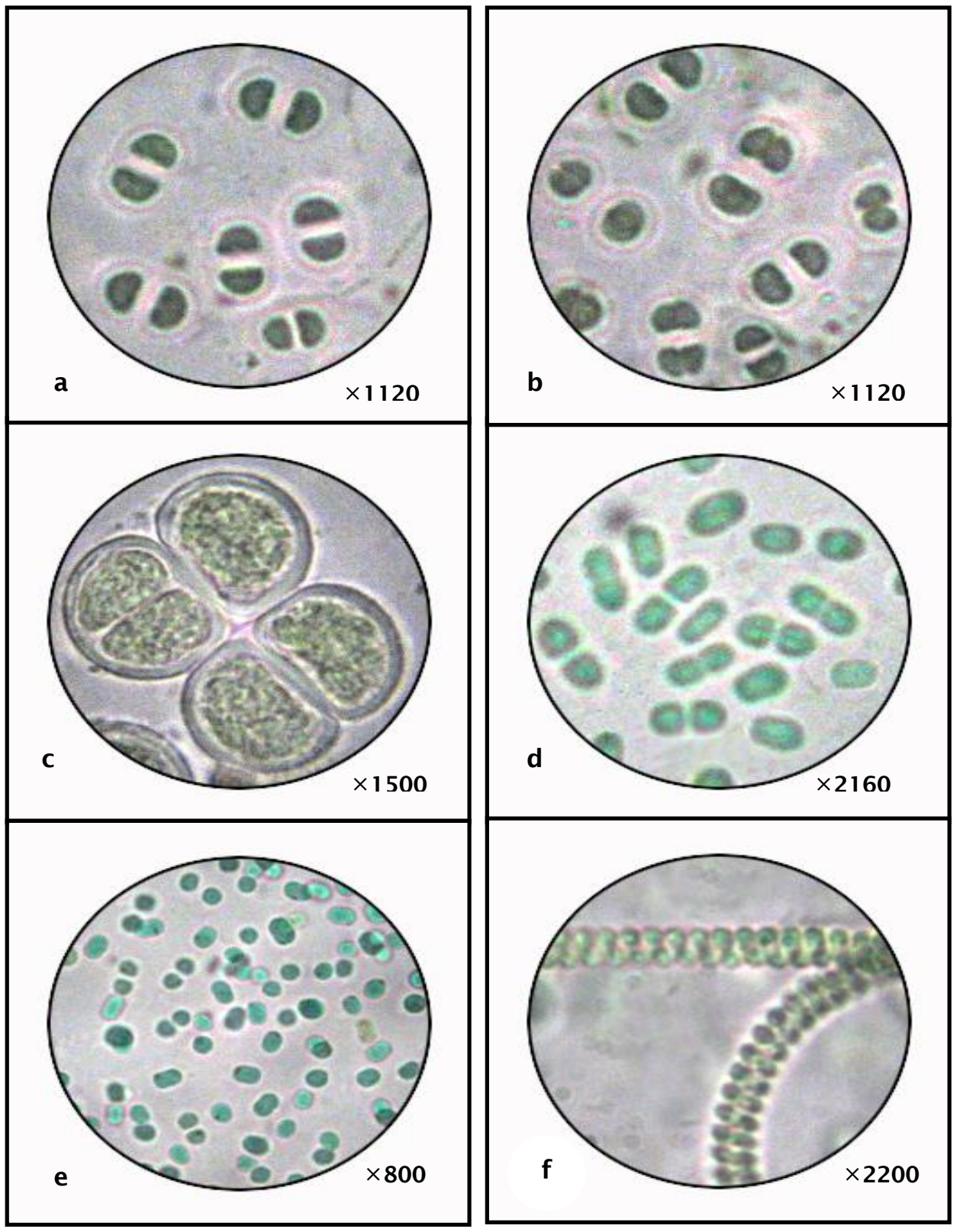

a. Cells of Chroococcus minor aggregated in pairs.

b. Colonies of $C$. minor with different division stages.

c. Four-celled colony of Chroococcus turgidus, not the initial fission of one of them.

d. Densely aggregation of Aphanothece castagnei with various cell shapes.

e. Cells of Aphanothece stagnina.

f. Tightly coiled spiral trichome of Spirulina subsalsa.

Egyptian J. of Phycol. Vol. 9, 2008

- 8 - 
Plate 2

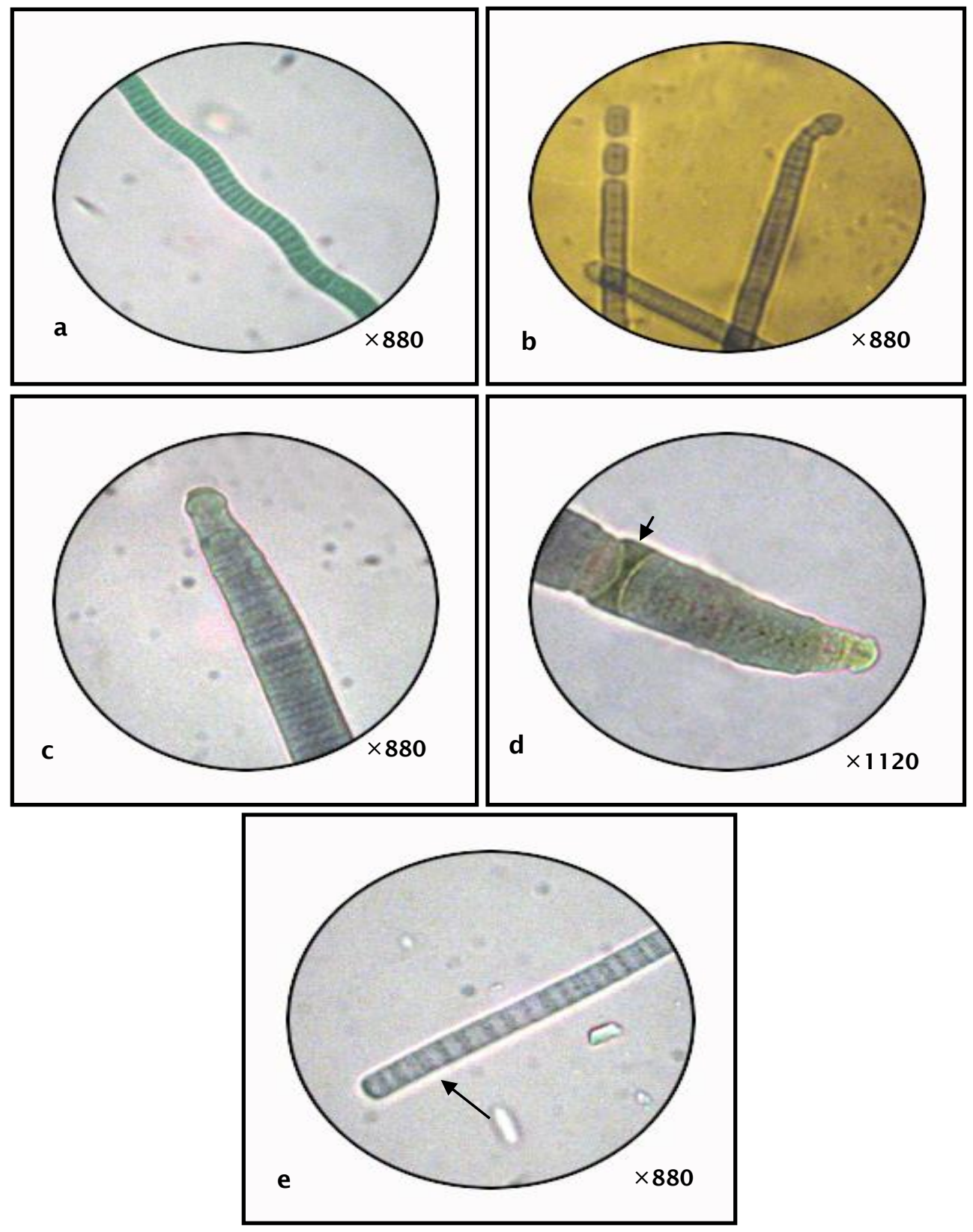

a. Loosely spiraled trichome of Arthrospira gomontiana var. crassa.

b. Trichome of Oscillatoria amoena, showing broad apical cell with conical or hemispherical calyptra, note hormogonia formation.

c. and d. Apex of Oscillatoria anguina trichome, the arrow shows the necridium.

e. Apex of trichome of Oscillatoria nigra, note the granulation at the cross walls.

- 9 - 


\section{Plate 3}
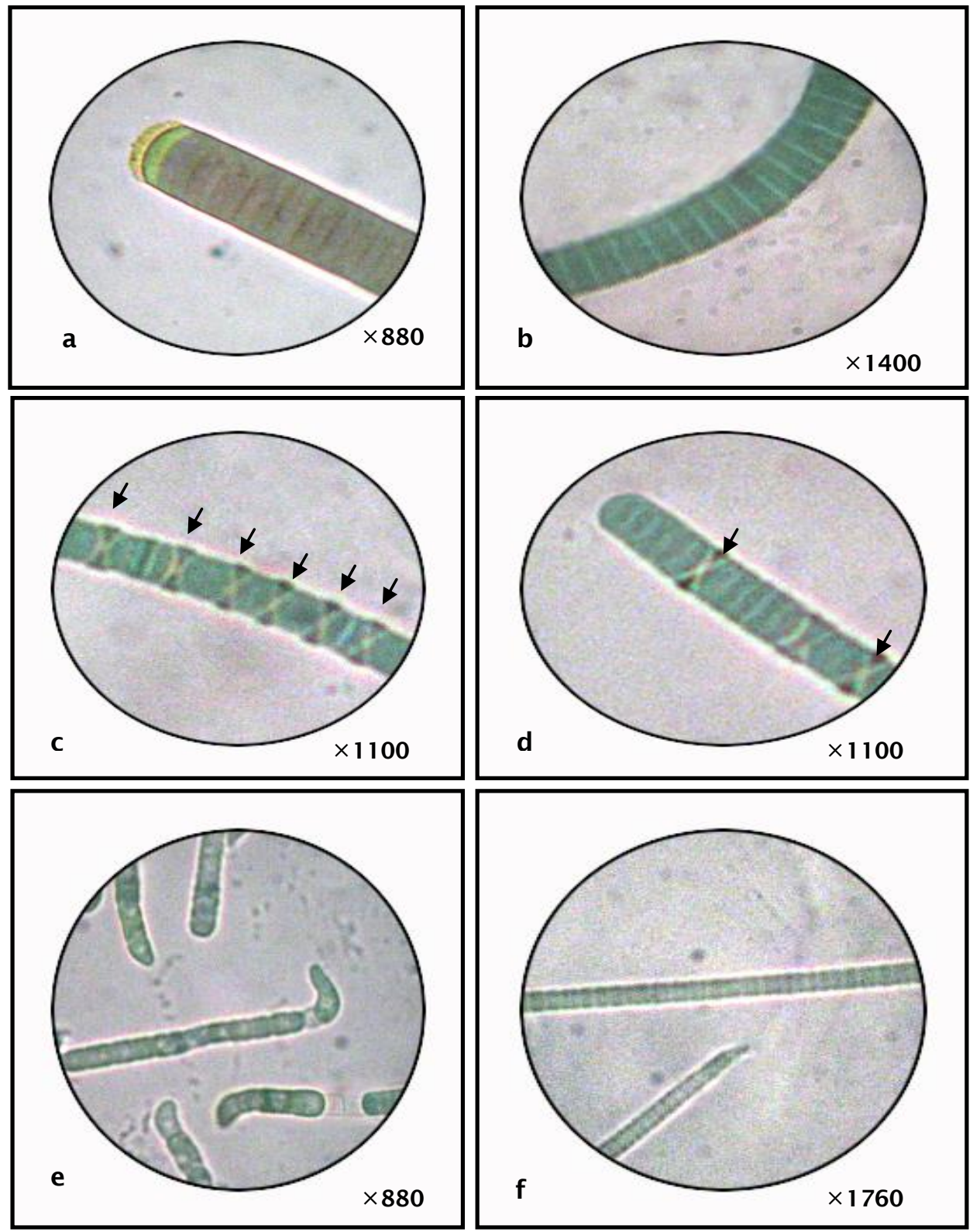

a. Apex of Oscillatoria sancta trichome, note the rotund apical cell with a calyptra.

b. Trichome of Oscillatoria subbrevis.

c. Trichome of $O$. subbrevis with frequency of necridia (note the arrows).

d. Apex of $O$. subbrevis trichome.

e. Trichomes of Oscillatoria $s p$ (1), note the hooked apex.

f. Trichomes of Oscillatoria sp (2), note acute-conical cell at the apex. 
Plate 4
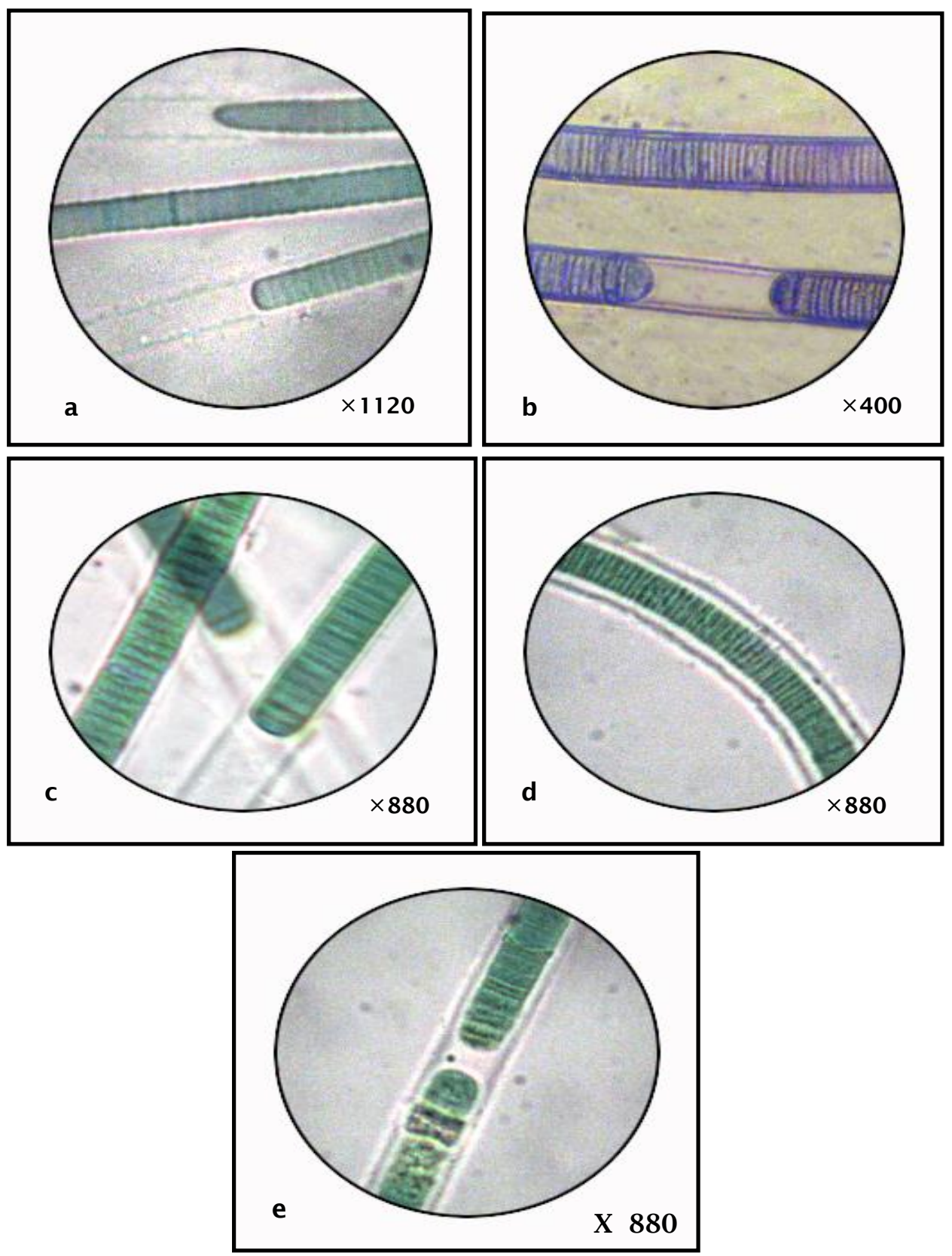

a. Filament of Phormidium ambiguum showing thin sheaths and trichomes.

b. Filament of Lyngbya birgei, note firm and thick sheaths.

c. Filament of Lyngbya hieronymusii showing the sheaths and trichomes.

d. Filament of Lyngbya martensiana showing sheath and trichome.

e. Filament of L. martensiana showing hormogonia formation. 


\section{Plate 5}
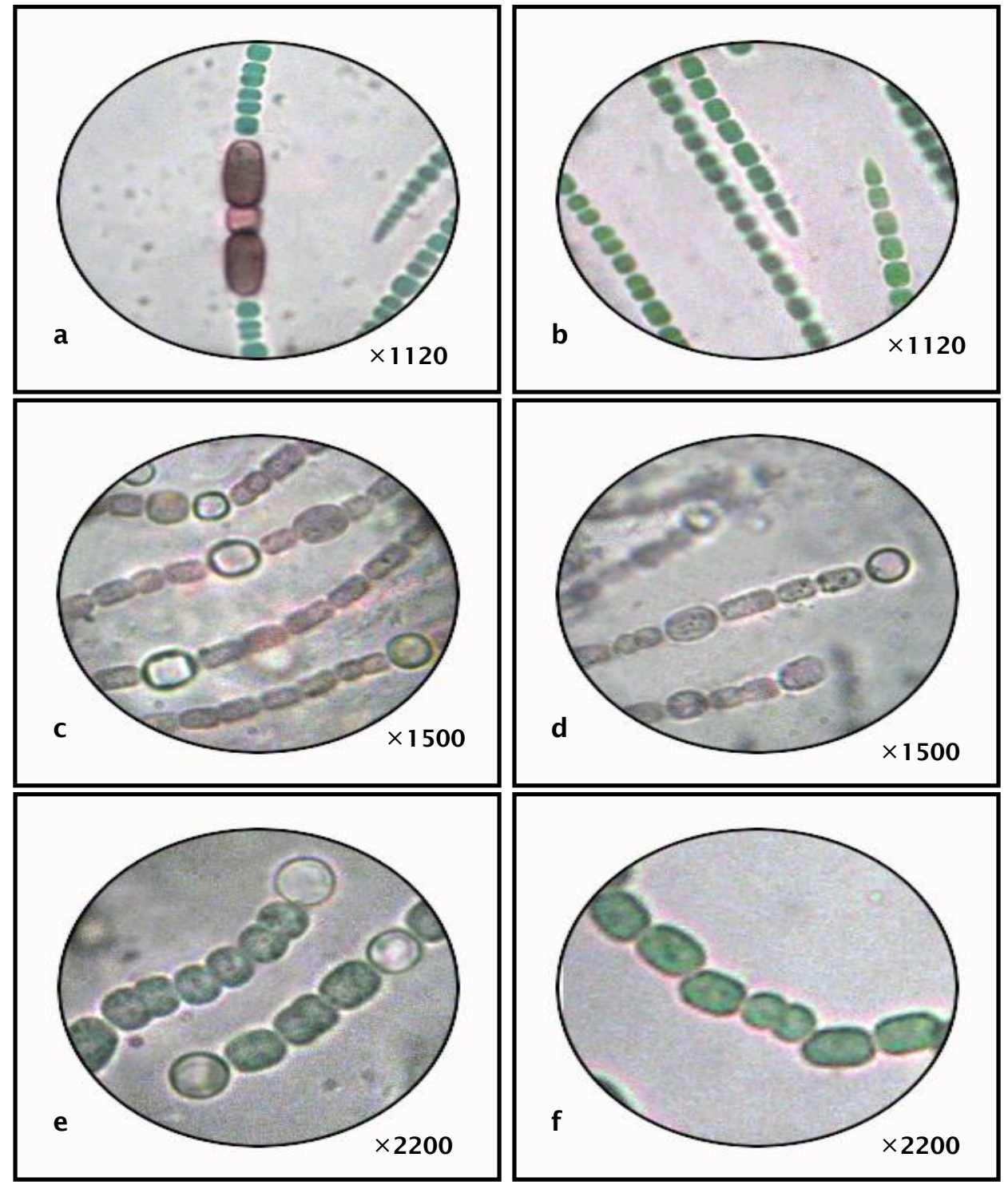

a. Anabaena torulosa, segment of a trichome with vegetative cells, heterocyst, and two akinetes, one in each side of the heterocyst.

b. A. torulosa, note the conical-shape of the apical cell.

c. Trichome of Anabaena wisconsinense showing the habit of thallus including vegetative cells, heterocysts.

d. Trichome of Anabaena wisconsinense showing akinetes.

e. Trichomes of Anabaena variabilis showing vegetative cells, and intercalary and terminal heterocysts.

f. A. variabilis showing a series of akinetes. 
Plate 6

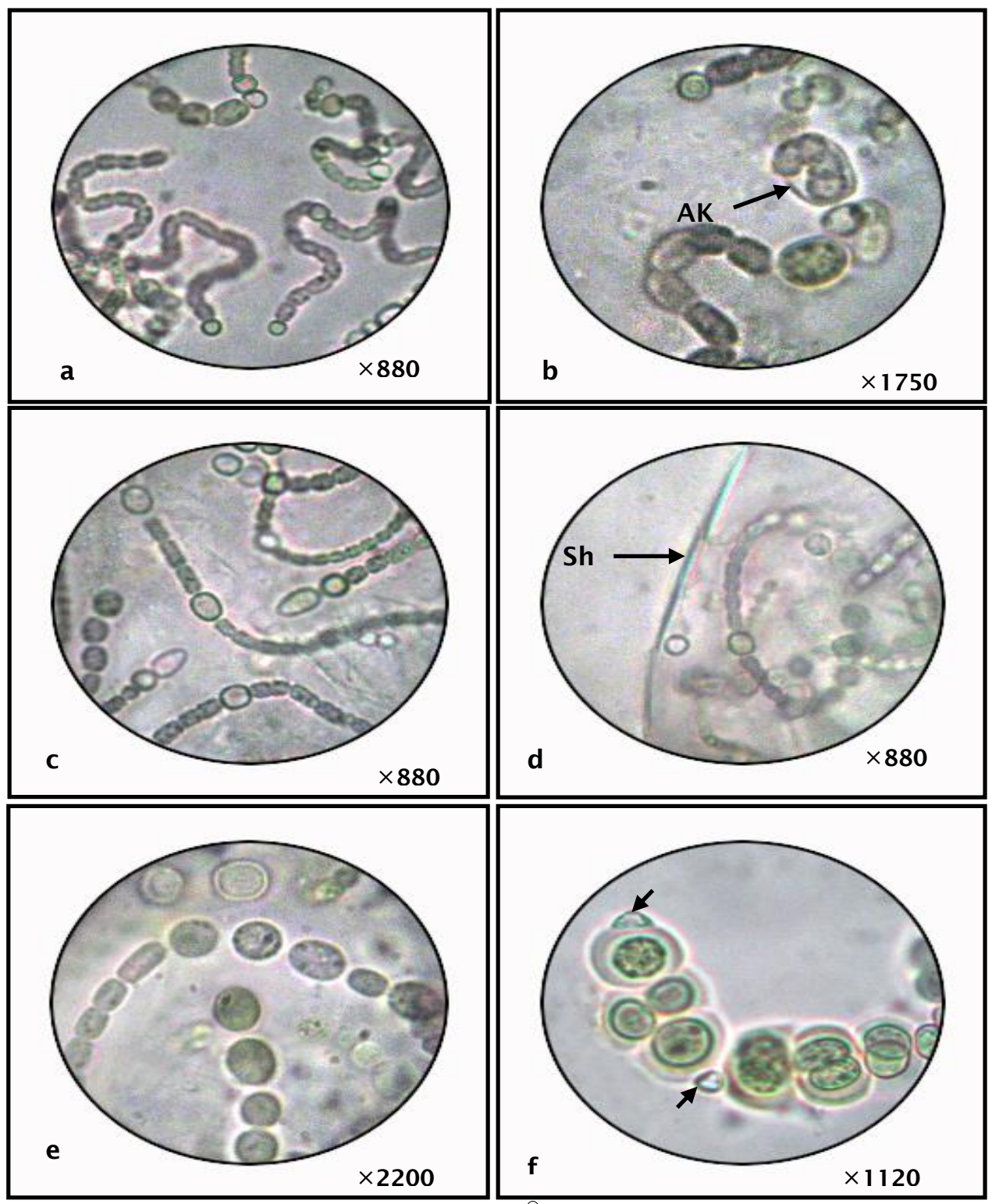

a. Part of entangled twisted trichomes of Nostoc linckia showing vegetative cells, intercalary and terminal heterocysts and akinetes.

b. $N$. linckia showing germination of akinete (AK).

c. Entangled, twisted trichomes of Nostoc paludosum showing vegetative cells, intercalary and terminal ovate heterocysts, and akinetes.

d. Few trichomes of $N$. paludosum loosely coiled in a gelatinous colonial sheath (Sh).

e. Short series of akinetes of N. paludosum.

f. the individual colonies of Nostoc sp. showing colonial sheath and the terminal heterocyst.

Egyptian J. of Phycol. Vol. 9, 2008

- 13 - 
Plate 7
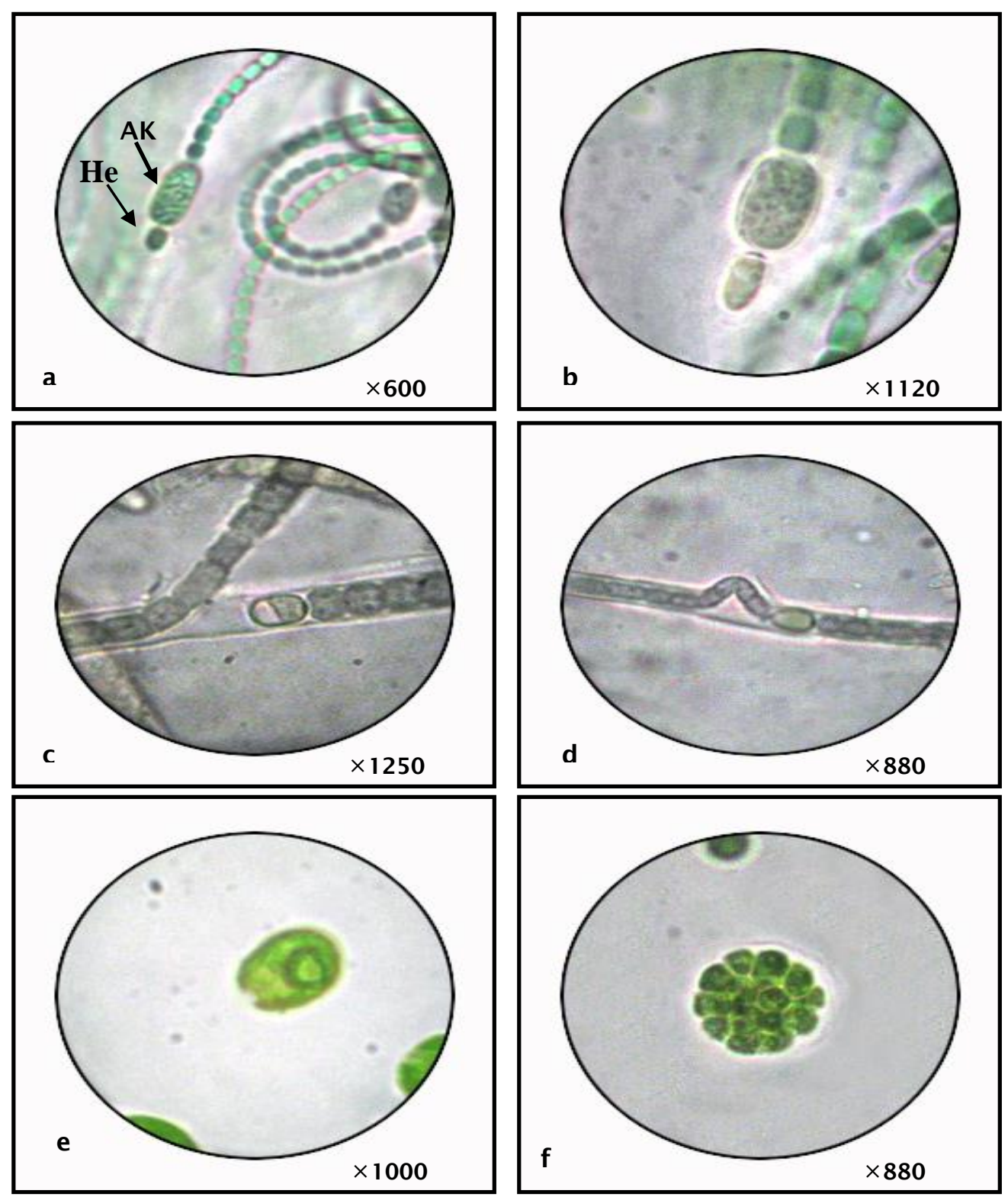

a. Trichomes of Cylindrospermum majus showing vegetative cells and the basal heterocyst (He) adjacent to solitary akinete (AK).

b. Cylindrospermum majus showing more highly magnified (b).

c. Filament of Tolypothrix tenuis showing single false branching

d. $T$. tenuis showing and beginning of the single false branching.

e. Vegetative cell of Chlamydomonas globosa, note the basal pyrenoid.

f. Coenobium of Pandorina sp. note the pear-shaped crowded cells. 


\section{Plate 8}
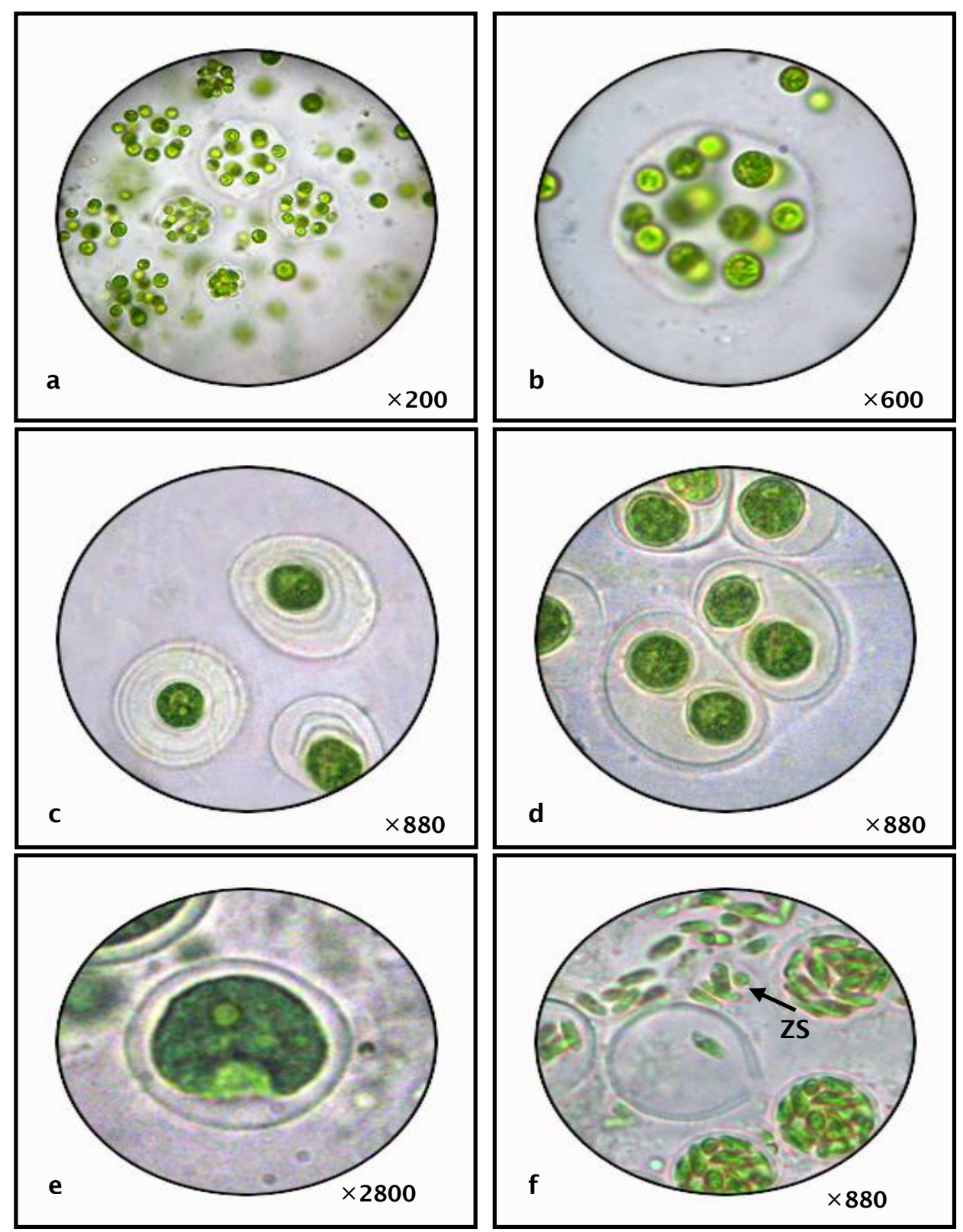

a. Coenobium of Eudorina sp.

b. Eudorina $s p$. more highly magnified, note the arrangement of spherical cells in different diamentions.

c. Solitary cells of Gloeocystis major showing the wide lamellated sheathes.

d. Gloeocystis major showing four-celled colony.

e. Chlorococcum humicola showing young vegetative cell.

f. C. humicola showing zoosporogenesis and zoospores (zs).

Egyptian J. of Phycol. Vol. 9, 2008

- 15 - 
Plate 9
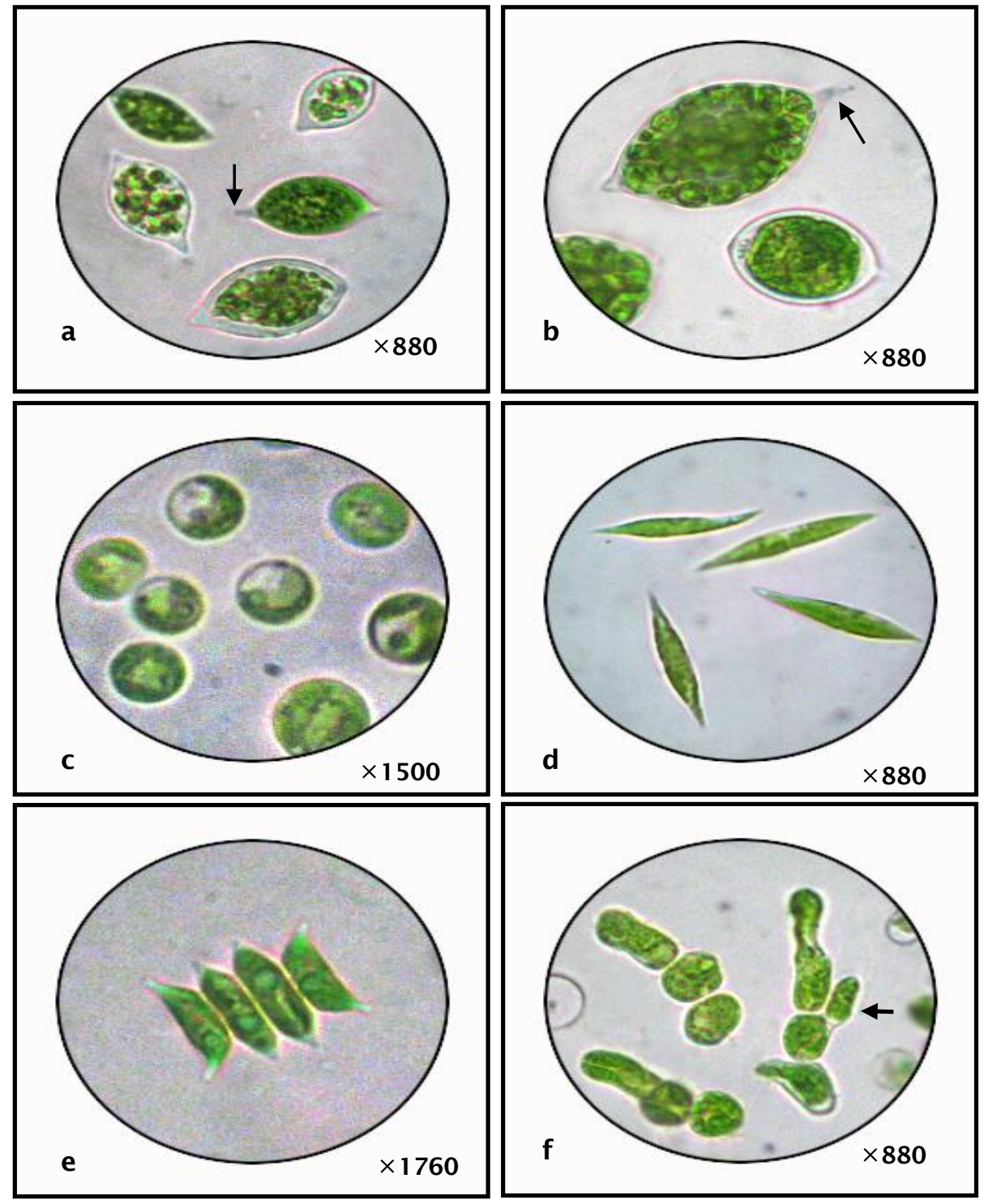

a. Characium acuminatum showing vegetative cells

b. C. acuminatum showing zoosporogenesis from the cell contents, the arrows refer to the short stipes.

c. Mature vegetative cells of Chlorella vulgaris.

d. Solitary mature vegetative cells of Ankistrodesmus braunii.

e. Highly magnified 4-celled colony of Scenedesmus dimorphus.

f. Protococcus viridis showing the organization to form simple filaments (the arrow points to the short branch). 
Plate 10

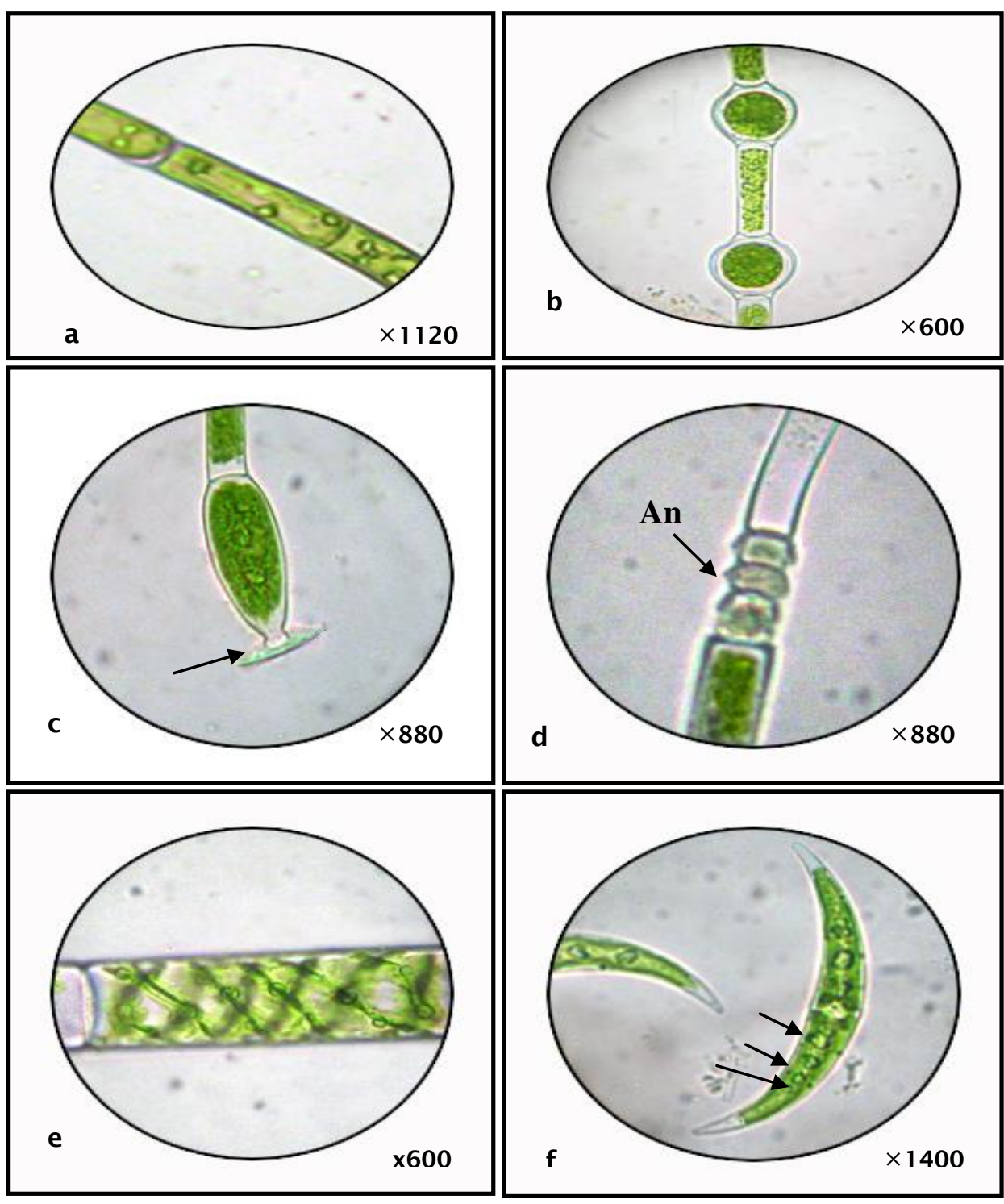

a. Mature filament of Ulothrix cylindricum showing the elongated cylindrical vegetative cells (note the parietal chloroplast with many pyrenoids.

b. Mature female filament of Oedoegonium lautumniarum showing vegetative cells and mature sexual female cells (oogonia) containing oospores.

c. O. lautumniarum showing basal holdfast (arrow).

d. O. lautumniarum showing mature male filament with antheridia (An).

e. Vegetative cell of Spirogyra sp. showing two parietal, ribbon-like, twisted chloroplasts with several pyrenoids.

f. Vegetative cells of Closterium parvulum (note the middle region and the arrangement of pyrenoids).

Egyptian J. of Phycol. Vol. 9, 2008

- 17 - 
Plate 11

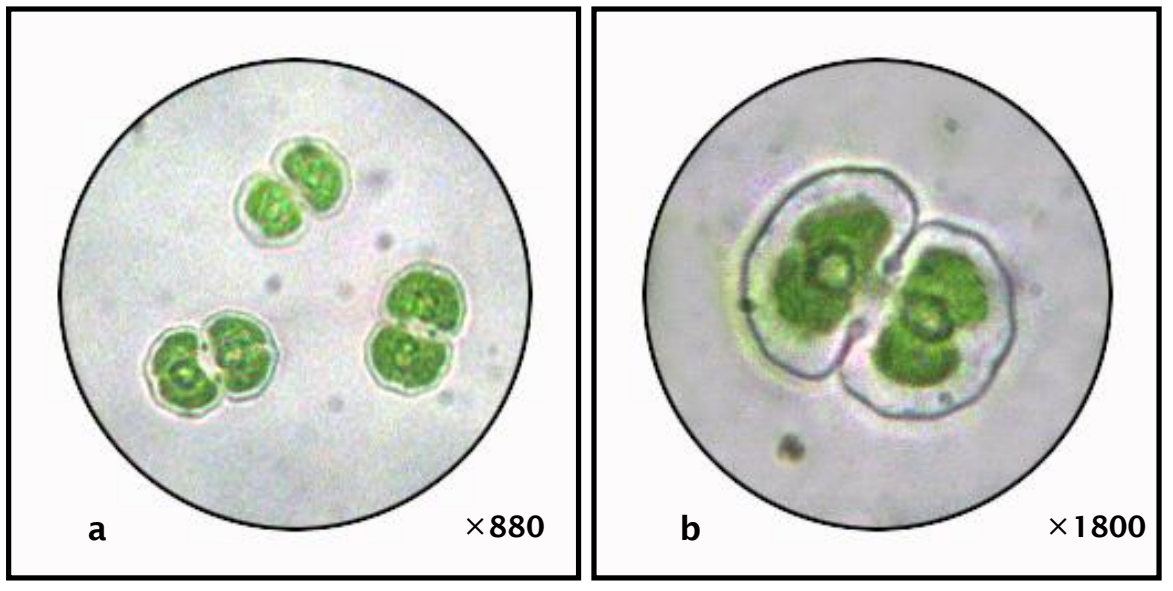

a. Vegetative cells of Cosmarium melanosporum

b. C. melanosporum showing magnified view of one cell (note the sinus at the mid-region, and the axial chloroplasts with one pyrenoid).

Table (4): Pearson correlation coefficient(r) between soil properties and number of algal isolates from different soil samples.

\begin{tabular}{|c|c|c|}
\hline \multirow{2}{*}{ Soil Properties } & \multicolumn{2}{|c|}{ Algal Division } \\
\hline & Cyanophyta & Chlorophyta \\
\hline Stones & -0.303 & 0.077 \\
\hline Fine gravel & -0.020 & 0.142 \\
\hline Medium sand & -0.130 & -0.244 \\
\hline Fine sand & $\begin{array}{l}-0.398 \\
\end{array}$ & -0.367 \\
\hline Very fine sand & $0.489^{* * *}$ & 0.086 \\
\hline Silt \& Clay & 0.048 & $0.389^{* *}$ \\
\hline MWHC & 0.069 & $\mathbf{0 . 3 8 3}^{*}$ \\
\hline Gravitational water & -0.173 & -0.373 \\
\hline Hygroscopic water & 0.099 & 0.349 \\
\hline Capillary water & 0.174 & $0.248^{*}$ \\
\hline T.W.S.S. & 0.241 & -0.385 \\
\hline E.C. & 0.246 & -0.339 \\
\hline pH & $\begin{array}{ll}-0.228 \\
\end{array}$ & 0.127 \\
\hline O.C. & $0.457^{* *}$ & 0.143 \\
\hline Carbonates & 0.316 *** & 0.064 \\
\hline Bicarbonate & $\begin{array}{l}-0.288 \\
\end{array}$ & $0.564^{* * *}$ \\
\hline Chlorides & $0.327^{*}$ & $-0.377^{*}$ \\
\hline $\mathbf{C a}^{+2}$ & 0.135 & $-0.251^{*}$ \\
\hline $\mathrm{Mg}^{+2}$ & $0.363^{*}$ & $-0.375^{*}$ \\
\hline $\mathrm{Na}^{+}$ & $0.297^{*}$ & $-0.359^{*}$ \\
\hline $\mathbf{K}^{+}$ & $0.275^{*}$ & $-0.359^{*}$ \\
\hline
\end{tabular}

* Correlation is significant at the 0.05 level; **Correlation is significant at the 0.01 level. 


\section{Discussion}

Distribution of soil algae depends largely upon many factors that might affect the existence of algae in soil. Soil is considered as a complex heterogenous environment which gives an impression of difficulty to draw a clear conclusion for the distribution pattern of algae. Hoffmann (1989) reported that edaphic factors and soil characters together with some specific features within algal organisms themselves constitute the main factors responsible for the existence of algae in soils. Area of Kafr El-Sheikh can be described as huge environment including a wide range of habitats: very strong saline, strong saline or non-saline habitats. All of the previous matters encouraged us to construct the first attempt to survey all geographic locations in such area as well as to investigate all possible extra -terrestrial algal life in Kafr El-Sheikh governorate. Although the Egyptian soil algal flora has been received certain attentions by many investigators (Fremy and Nasr, 1938; Aleem, 1950; El-Ayouty and Ayyad, 1972; Kobbia and Shabana, 1988 ; El-Gamal, 1990; Ahmed, 1994; El-Gamal,1995; El-Sheekh et al.,1998; ElAttar, 1999; Mahmoud et al., 2000; El-Naghy et al., 2004; Shanab, 2006), it is still some ambition to draw more about their role in ecosystems. The variations of present soil texture from one region to the other may have a role in algal distribution. There was a significant positive correlation between very fine sand and cyanobacteria species, whereas silt and clay exhibited a significant positive correlation with green algal species. In this respect, Büdel and Lange (2003) reported that cyanobacteria generally dominate soils that are very sandy (> $90 \%)$ and very salty, regardless of climatic zone. Also, the present result indicates the role of silt and clay in selecting and distribution of green algae. The importance of fine particles leads to the availability of more total exposed surface in such soil over that possessing coarse soil particles (Cano et al., 1997). Another explanation may be due to that physical properties of soil are more often associated with finetextured soils over possessing coarse textured soils. However, little is known about data to clarify this debate. These findings were in part in accordance with those observed by Salama et al. (1973) and Osman et al. (2003). In contrast, the results obtained by Fathi and Zaki (2003) indicated that the response of algal biomass at the different investigated sites to soil texture is not reflected in retarded or activated algal growth. The Chlorophyta species showed significant positive correlation with the percent of maximum water holding capacity and capillary water, while there is no correlation with Cyanophyta species. This may due to other factors affect their distribution. On the other hand, Metting (1981) reported the ability of cyanobacteria to survive under variable and even adverse conditions.

Results of the present study showed that most of investigated soils which collected from waste lands are saline soils, while the others are non-saline. Various E.C. levels of different investigated soils can be divided the soils into two groups: strong and very strong salinity levels. With respect to all present salinity 
levels, the numbers of Cyanophyta were not affected while, the numbers of Chlorophyta decreased. This is supported by data of correlation coefficient between E.C. and algal species (Table 4).The presence of numerous Cyanophyta as compared to other types of soil algae is a matter of tolerance and adaptability (Metting, 1981). Most of the investigated soils have a slightly alkaline nature and this in turn explain the dominance of Cyanophyta over than the Chlorophyta groups. The results obtained are in agreement with these findings of El-Gamal (1995).

In the present study, it was noticed that there is a significant positive correlation between organic carbon, carbonates, chlorides, $\mathrm{Mg}^{+2}, \mathrm{Na}^{+}, \mathrm{K}^{+}$and Cyanophyta. Chlorophyta species showed a significant negative correlation with chlorides, $\mathrm{Ca}^{+2}, \mathrm{Mg}^{+2}, \mathrm{Na}^{+}$and $\mathrm{K}^{+}$ions. The dissimilarity demands of both investigated algal groups reflected that these factors not only affecting the distribution pattern among different algal groups but also controlling the algal growth. Generally, the present results give at first sight an impression for the importance of cation contents for the growth and abundance of algae as well as, their productivity. This is in accordance with the results by Fathi and Zaki (2003).

Results of the present investigated soil algae (Table 3), showed that soil sample 6 exhibited the highest number of species (13 algal species), representing $32.5 \%$ of the total number of isolated algal species. On the other hand, soil 10 showed the lowest number of isolates ( 3 species), representing $7.5 \%$ of the total isolated species.

According to author's knowledge Ulothrix cylindricum, Oedogonium lautumniarum and Spirogyra sp have not been previously reported in Kafr ElSheikh Governorate and are considered as new records for these areas. In general, and on the basis of obtained data herein the fine textured nature of soil, organic carbon content, carbonates, bicarbonates and mono-and divalent anions are the most highly significant factors affecting the abundance and species of soil algae.

This survey also revealed that not only the coccoid forms of green algae are represented but also other filamentous and colonial forms of Chlorophyta are well represented. According to such findings, it can be concluded that the occurrence of soil algae in a wide variety of habitats is still less studied than that of other microorganisms such as soil fungi and bacteria, and this gives us difficulty to generalize about them. Most of the present soil samples were collected lacking macroscopically evident algal growth with the exception of some filamentous cyanobacteria such Oscillatoria spp., Lyngbya spp. which were detected with light microscope in the majority of examined samples. Other isolates were mostly obtained through culture techniques. Hence, the culture methods of soil algae seem to be of great value in distinguishing algal taxa and useful if they provide more information than what is evident from natural populations. 


\section{References}

Ahmed, Z.A. (1994). Preliminary survey of soil algal flora in Upper Egypt. Egypt. J. Bot., 34(1): 17-36.

Aleem, A.A. (1950). Some Cyanophyta from the eastern Mediterranean; Sartryckur.Meddelandenn from Coteborgs Boptaniska Tradgord 18.

Bailey, D.; Mazurak, A.P. and Rosowski, J.R. (1973). Aggregation on soil particles by algae. J. Phycol., 9: 99 pp.

Büdel, B. and Lange, OL. (2003). Synopsis: Comparative biogeography and ecology of soil-crust biota and communities. In Biological soil crusts: Structure, Function and Management, belnap J, Lange, O.(eds.). springer- Verlag : Berlin; 141-152.

Cano, M.S.; Mule,M.C.Z.; de Caire, G.Z.; de Palama, R.M. and Colombok, K. (1997). Aggregation of soil particles by Nostoc muscorum Ag.( Cyanobacteria). International J. of Expermintal Botany.60 (2): 33-38.

Darley, W.M. (1982). Algal Biology: A Physiological Approach, Blackwell Scientific Publications, Oxford.

El-Attar, S.A. (1999). Studies on the soil algal flora at Qalyubia province, Egypt. Egypt. J. Bot., 39: 127-145.

El-Ayouty. E.Y. and Ayyad, M.A. (1972). Studies on blue-green algae of the Nile Delta-1-Description of some species in a wheat field. Egypt. J. Bot., 15: 283-321.

El-Gamal, A.D. (1990). Studies on the algal flora of a cultivated land (El-Khanka District) according to cultivation succession. M.Sc. Thesis, Faulty of Science, Al-Azhar University, Cairo, Egypt.

El-Gamal, A.D. (1995). Systematical studies on the algae isolated from some cultivated areas and laboratory studies on the effect of light, temperature and humidity on three selected soil algae. Ph.D. Thesis, Fac. of Sci., AlAzhar University, Cairo, Egypt.

El-Naghy, M.A.; El-Shahed, A.M.; Fathi, A.A.and Ahmed, G.El-Din G. (2004). Algal flora of rice fields at El-Kharg Oasis, Egypt. Egypt J.Phycol.5:51-69.

El-Nawawy, A. S.; Lotfi, M. and Fahmy, M. (1958). Studies on the ability of some blue-green algae to fix atmospheric nitrogen and their effect on growth and yield of paddy. Agric. Res. Rev., 36(2):308-320.

El-Sheekh, M.M.; El-Behiry, M.A.and El-Kady, H.F. (1998). Soil algae of Thymelaea hirsute and Asphodelus microcarpus in Mediterranean desert of Egypt.Egypt.J.Bot.38 (1-2):185-204.

Esmarch, F. (1914). Untersuchungen über die Verbreitung der Cyanophyceen auf und in Verschiedenen Böden Hedwigia. B. 55: 224-273.

Fathi, A.A. and Zaki, F.T. (2003). Preliminary survey of edaphic algae in ElMinia region, Nile valley, Egypt. Egyptian J. of Phycol. 4(2): 131-148. 
Fremy, P.and Nasr, A.H. (1938). Two new Cyanophyta from the Red Sea. Bull.Fac.Sci, 18, 31.

Gray, T.R.G. and Williams, S.T. (1971). Soil microorganisms, Hafiner, New York.

Handley, W.J. and Michelle, A.H. (2003). The distribution pattern of algal flora in saline lakes in Kambalda and Esperance, Western Australia. Master's Thesis ( by research) Master of Science. Department of Environmental Biology.

Hoffmann, L.(1989). Algae of Terrestrial Habitats. The Bot. Rev. 55 (2): 77-105.

Hu, C.X; Liu, Y.D.; Paulsen, B.S.; Petersen, D.and Klaveness, D.(2003). Extracellular carbohydrate polymers from five desert soil algae with different cohesion in the stabilization of fine sand grain, Carbohydrate Polymers 5: 33-42.

Ibraheem, B.M.I.(2003). Preliminary survey of microbial soil crusts in a xeric habitats ( Wadi- Araba, Eastern desert, Egypt). Egypt. J.Phycol., 4:1935.

Jackson, M.L. (1977). Soil Chemical Analysis. Prentice Hall of Indian. Private Limited-New Delhi.

Kobbia, I.A. and Shabana, E.F. (1988). Studies on the soil algal flora of Egyptian Bahariya Oasis. Egypt. J. Bot., 31: 23-43.

Lund, J.W.G. (1945). Observations on soil algae. I. The ecology, size and taxonomy of British soil diatoms, Part I, New Phytologist. 44:196-219.

Mahmoud, S.A.; Ahmed, A.; Issa, A.A. and Awatief, F.H. (2000).The effect of pollution on the community soil algae on the Nile bank at Assiut, Egypt. Acta Hydrobiol.42:9-20.

Metting, B. (1981). The systematic and ecology of soil algae, Bot. Rev., 47: 195312.

Osman, M.E.H.; El-Naggar, A.; Omar, H.H.and Esmail, G.H.(2003).Distribution of different soil algal taxa in relation to physico-chemical characteristics of soil at Gharabia governorate.Egypt.J.Phycol.,4:36-54.

Page, A.L.; Miller, R.H. and Keeney, D.R. (1982). Methods of soil analysis, Part 2. Chemical and microbiological properties. Amer. Soc. of Agron. Madison, Wisconsin, USA.

Painter, T.J. (1993). Carbohydrate polymers in desert reclamation - the potential of microalgal biofrtilizers. Carbohydrate polymers, 20: 77-86.

Piper, C.S. (1950). Soil and Plant Analysis. Interscience Ins., New York.

Prescott, G.W. (1973). Algae of the Western Great Lakes area. $5^{\text {th }}$ ed., revised ed. (1982), WM. C. Brown Publishers, Dubu-que, Lowa.

Round, F.E. (1981). The ecology of algae. Cambridge University Press, Cambridge. 
Salama, A.M.; El-Batanouny, K. and Ali, M.I.(1973).Studies on the fungal flora of Egyptian soils. I. West Mediterranean Coast and Lybian Desert.U.A.R.Bot.14:99.

Shanab, Sanna, M.M. (2006).Algal flora of Ain Helwan.II.The soil algae.Egypt.J.Phycol.,7:221-235.

Shield, L. M. and Drouet, F. (1962). Distribution of terrestrial algae within the Nevada test site. Amer. J. Bot., 49:547-554.

Shields, L.M. and Durrell, L.W. (1964). Algae in relation to soil fertility. Bot. Rev., 30: 92-128.

Shubert, L.E. and Starks, T.L. (1980). Soil algae relationships from surface mined soils. Br. Phycol. J. 15: 417-428.

SPSS Statistical PC program (1997).SPSS for windows standard version.Copright @SPSS.Inc.http://spssscience.com

Staub, R. (1961). Ernährungsphysiologisch - autökologische Untersuchengen an der planktischen Blaualg Osillatoria rubescens D.C.Schweiz Zeitschr. Hydrologie. 23:82-198.

Walkely, A and Black, I.A. (1934). An examination of the Degtjareff method for determining soil organic matter and a proposed modification of the chromic acid titration method. Soil Science, 37: 29-38.

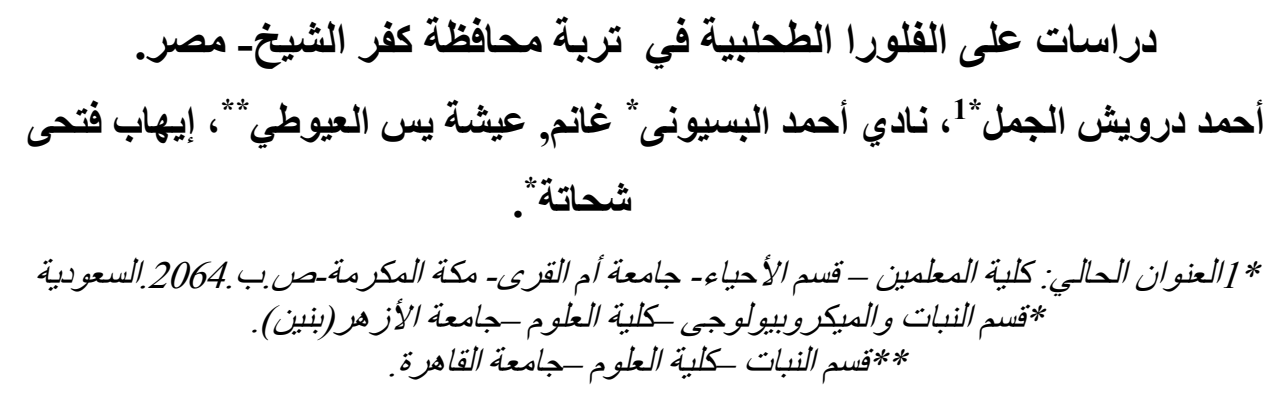

تم في هذا البحث دراسة الفلورا الطحلبية في تربة محافظة كفر الثيخ، إحدى محافظات الوجه البها

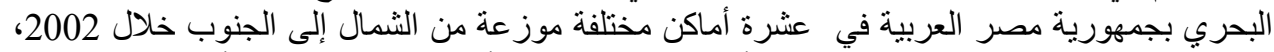

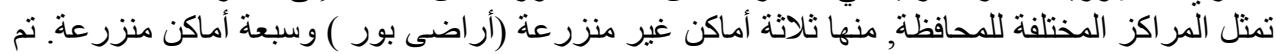

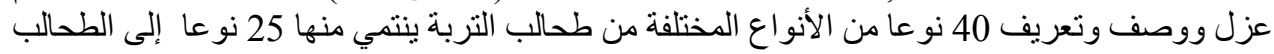

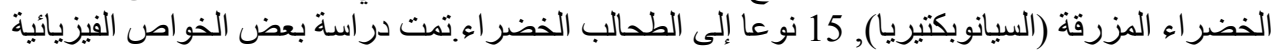

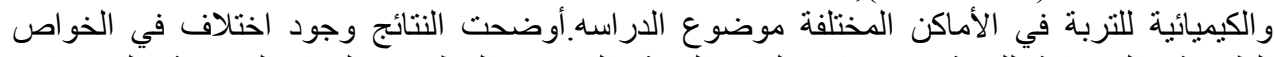

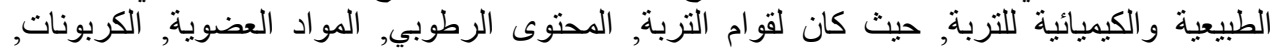

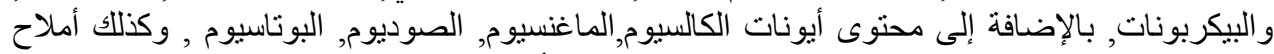
الكلوريدات الدور الهام الذي ارتبط به توزيع الطحالب إيجابا أو سلبا. 